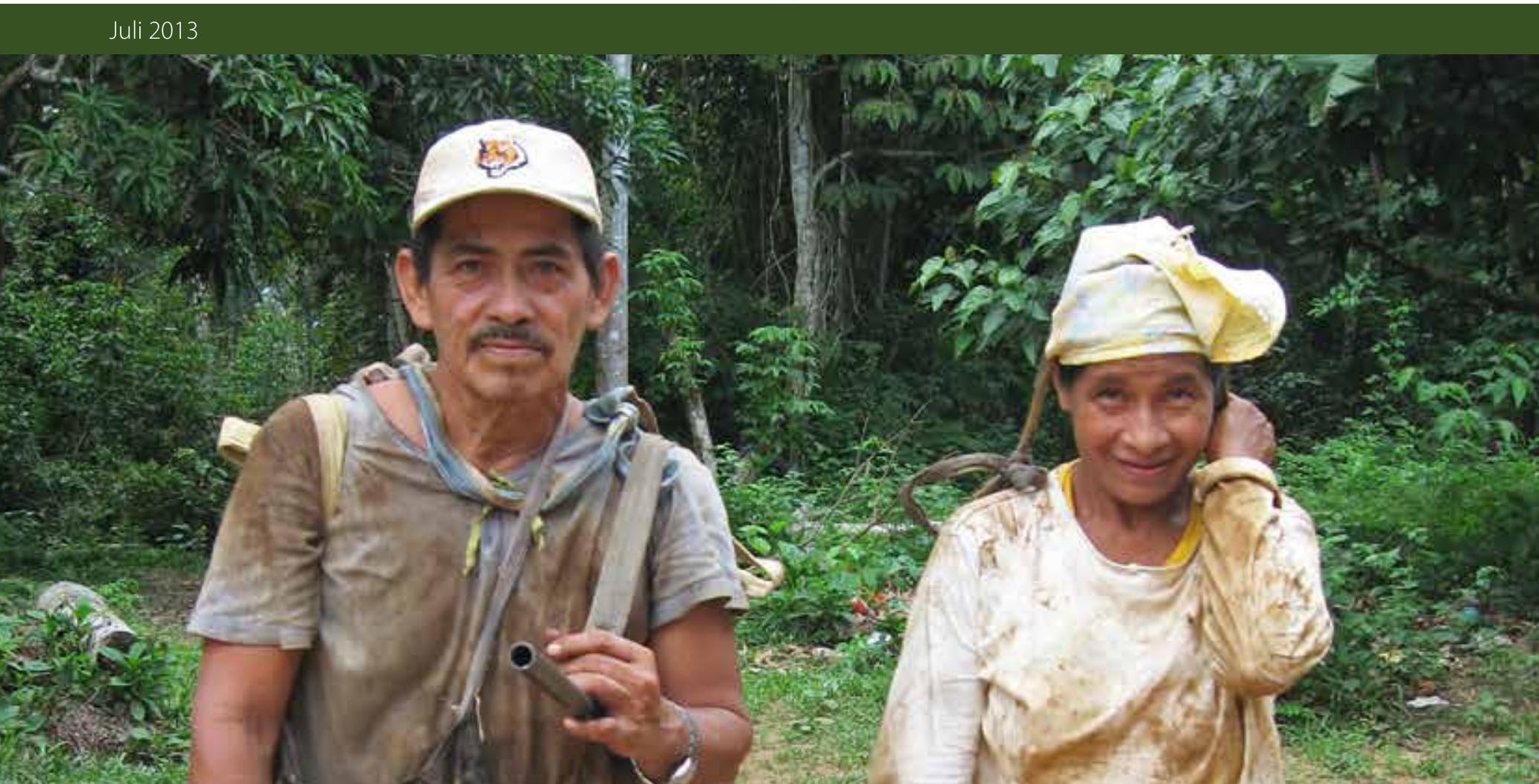

\title{
Apakah proposal Anda telah menunjukkan perhatian yang cukup terhadap isu jender?
}

Sebagai seorang peneliti CIFOR, Anda sekarang diminta untuk secara aktif mempertimbangkan apakah dan bagaimana jender relevan dalam penelitian Anda. Memadukan jender dalam penelitian merupakan bagian mendasar dari pengaplikasian ilmu pengetahuan yang tepat, suatu sarana untuk membantu memastikan bahwa penelitian kehutanan mengarah pada kemajuankemajuan yang setara secara sosial untuk kesejahteraan manusia dan konservasi lingkungan. Memadukan jender akan memampukan Anda untuk menulis proposal yang lebih kompetitif dan mendorong munculnya hasil-hasil penelitian yang lebih relevan dan bertahan lebih lama. Panduan singkat ini menyediakan beberapa pertanyaan kunci untuk membantu memastikan proposal Anda kepada CIFOR memperlihatkan perhatian yang cukup terhadap isu-isu jender.

Penelitian yang responsif-jender menyelidiki berbagai prioritas dan kebutuhan yang berbeda dari laki-laki dan perempuan. Penelitian ini juga menganalisis bagaimana hubungan jender memengaruhi kemampuan laki-laki dan perempuan untuk mengelola dan memanfaatkan hutan dan hasil-hasil hutan, dan juga mengenai bagaimana berbagai kebijakan memengaruhi perempuan dan laki-laki secara berbeda. Penelitian bertujuan untuk mengidentifikasi penyebab yang mendasari ketidaksetaraan jender. Ini melibatkan pengumpulan data yang dipilah berdasarkan jenis kelamin dan menganalisis ketidaksetaraan jender untuk meneliti bagaimana ketidaksetaraan ini memengaruhi berbagai kelompok manusia yang berbeda. Penelitian terfokus pada jender lebih cenderung untuk dilaksanakan secara kolaboratif dengan masyarakat dan pemangku kepentingan lainnya untuk mencapai cakupan dan kegiatannya. Rekomendasi dari penelitian ini akan mengidentifikasi perbaikan untuk kebijakan kehutanan dan praktik-praktik yang menawarkan berbagai pilihan terbaik untuk semua pihak dan bertujuan untuk mengatasi ketidakseimbangan aset atau kekuasaan.

\section{Tujuan dan Sasaran}

Dalam merancang penelitian Anda, tujuan dan sasaran Anda harus secara eksplisit memperlihatkan sumbangsih terhadap kesetaraan yang lebih besar dan pengurangan kemiskinan yang konsisten dengan tujuan CIFOR dan dengan Hasil-hasil Tingkat Sistem (System Level Outcomes) CGIAR.

Pada taraf minimum, sasaran dan hasil dapat mengacu secara khusus pada laki-laki dan perempuan, tidak hanya menyebutkan "para petani" atau "anggota masyarakat". Namun, usahakan untuk menempatkan tujuan, sasaran dan pertanyaan-pertanyaan penelitian agar menunjukkan jender sebagai variabel kunci dan bebas meski variabel sosial lain juga diteliti. Tidak semua proyek dapat mencakup suatu perspektif jender. Meskipun demikian, penting untuk memperlihatkan bahwa dalam penelitian tersebut, Anda telah mempertimbangkan untuk dapat memberi sumbangsih pada kesetaraan yang lebih besar atau menerapkan kotak alat bantu analisis jender (Kotak 1).

- Apakah Anda telah menunjukkan bagaimana penelitian Anda akan responsif terhadap atau berfokus pada isu jender? Ini dapat diperlihatkan dengan bagaimana Anda menempatkan tujuan, sasaran atau berbagai pertanyaan penelitian dalam proposal Anda. 


\section{Kotak 2. Mencari pertanyaan-pertanyaan penelitian terkait jender?}

Silakan cek referensi berikut:

- CIFOR. 2013. Gender in the CGIAR Research Programme on Forests, Trees and Agroforestry: A Strategy for research and action. Bogor, Indonesia: CIFOR.

- Manfre C. dan Rubin D. 2012. Integrating Gender into Forestry Research: A Guide for CIFOR Scientists and Programme Administrators. Bogor, Indonesia: CIFOR.

- CIFOR. 2011. CGIAR Research Programme 6 (Program Penelitian CGIAR 6): Forests, Trees and Agroforestry: Livelihoods, Landscapes and Governance. Proposal. Bogor, Indonesia: CIFOR.

jenis kelamin? Karena suatu analisis jender adalah mengenai hubungan antara laki-laki dan perempuan, yang bergantung pada data yang relevan dan valid mengenai keduanya, bukan hanya pada perempuan atau laki-laki saja.

- $\quad$ Apakah Anda telah mempertimbangkan metode apa saja yang paling sesuai dengan skala penelitian tersebut? Bila Anda membandingkan lintas negara, survei mungkin lebih tepat, sementara metode-metode partisipatif mungkin lebih berguna untuk meneliti berbagai perubahan tentang akses hak-hak terhadap hutan di kawasan spesifik. Pendekatan partisipatif dan kolaboratif umumnya lebih cocok diterapkan jika ingin bekerja dekat dengan, atau memberdayakan masyarakat lokal.

- Apakah Anda telah mempertimbangkan metode apa yang paling sesuai untuk khalayak sasaran penelitian Anda?

- Apakah Anda telah mempertimbangkan kebutuhan para penyensus atau pewawancara laki-laki dan perempuan? Tergantung pada konteks budaya untuk penelitian tersebut, kaum lelaki harus mewawancarai lelaki dan/atau kaum perempuan harus mewawancarai perempuan.

- Apakah Anda mempertimbangkan perlunya merencanakan wawancara jenis kelamin tunggal dan/ atau campuran, diskusi kelompok terfokus atau kegiatan partisipatif lainnya?

\section{Kotak 3. Perhatikan komposisi jender tim Anda.}

Meningkatkan kesempatan untuk kaum perempuan dalam ilmu pengetahuan dan penelitian merupakan sasaran penting untuk CIFOR dan CGIAR. Banyak pendukung dana, seperti Uni Eropa, juga semakin memberikan perhatian tidak hanya pada bagaimana jender dimasukkan dalam konten penelitian, tetapi juga pada seberapa bagus berbagai lembaga mendukung kesempatan yang setara dalam berbagai kebijakan dan praktik mereka. Memasukkan perempuan dalam tim penelitian Anda tidak berarti bahwa konten penelitian Anda atau hasilnya lebih peka jender. Namun, mempromosikan kesempatan yang setara untuk laki-laki dan perempuan untuk berperan serta dalam penelitian merupakan satu langkah maju untuk membangun budaya kerja yang mengizinkan baik laki-laki maupun perempuan untuk berkembang.

\subsection{Kemitraan dan Aliansi}

- Apakah Anda memasukkan kelompok-kelompok wanita atau organisasi lain yang bekerja mendukung kesetaraan jender atau hak-hak perempuan di antara mitra-mitra penelitian Anda? Kemitraan dan aliansi dapat dibina oleh berbagai kelompok seperti misalnya komite jender nasional atau daerah, kementerian jender atau urusan perempuan, atau organisasi-organisasi perempuan atau asosiasi bisnis.

- $\quad$ Apakah Anda memasukkan kelompok-kelompok wanita atau organisasi lain yang bekerja mendukung kesetaraan jender atau hak-hak perempuan untuk advokasi dan penjangkauan?

\subsection{Berbagi pengetahuan untuk kebijakan dan praktik}

- Apakah Anda telah menjelaskan bagaimana pencatatan statistik, tabel, angka-angka, deskripsi dan analisis yang tidak dipilah berdasarkan jender?

- Apakah Anda telah memasukkan hasil kerja spesifik, publikasi atau acara untuk menunjukkan temuantemuan terkait jender?

- Apakah Anda telah memasukkan rencana untuk mengedarkan temuan kepada para penerima manfaat,

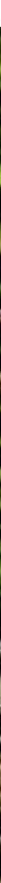


termasuk kaum perempuan? Ketika Anda melaporkan hasil kepada masyarakat, pastikan bahwa kaum perempuan dapat memahami dan mengakses berbagai temuan tersebut.

- $\quad$ Apakah Anda telah mempertimbangkan bagaimana berbagi pengetahuan dengan kelompok-kelompok perempuan, komite atau kelompok-kelompok lain yang mendukung kesetaraan jender atau hak-hak perempuan?

\section{Pembangunan kapasitas}

- Apakah Anda telah mempertimbangkan kebutuhan akan pelatihan untuk memastikan anggota tim peneliti memiliki pemahaman yang sama mengenai jender?

- Apakah Anda telah mempertimbangkan kebutuhan untuk melatih para penyensus tentang analisis jender?

- Apakah Anda telah mempertimbangkan kebutuhan akan suatu lokakarya mengenai alat bantu atau metode untuk analisis jender?

- $\quad$ Apakah Anda telah mengidentifikasi pakar-pakar jender atau organisasi yang dapat mendukung tim Anda dalam seluruh proses penelitian tersebut?

\section{Pembelajaran Adaptif}

- Apakah Anda telah memastikan bahwa indikator tingkat-manusia Anda tidak dipilah berdasarkan jenis kelamin? Ini berarti akan ada lebih banyak data tidak terpilah pada tingkat rumah tangga. Penelitian Anda harus bersifat tidak dipilah berdasarkan jenis kelamin untuk setiap indikator yang melacak jumlah atau persentase orang.

- Apakah Anda telah memasukkan berbagai indikator tidak terpilah jenis kelamin pada tingkat hasil untuk mengukur perubahan pengetahuan, kapasitas atau perilaku dari populasi target?

- Apakah Anda telah mempertimbangkan berbagai indikator untuk mengukur dampak utama terkait jender yang tertera dalam Program Penelitian CGIAR terhadap Hutan, Pohon dan Wanatani? Hal-hal ini mencakup:

- Kemajuan menuju pencapaian kesetaraan jender dalam pengambilan keputusan dan pengendalian terhadap sumber daya hutan, pohon dan wanatani dan dalam peningkatan pendapatan dan manfaat untuk kaum perempuan melalui hasil rantai nilai yang relevan

- Lebih banyak perempuan yang baru diberdayakan untuk menanam dan mengelola sumber daya hutan, pohon dan wanatani di negara-negara program;

- Berkurangnya ketidaksetaraan jender dalam pendapatan dari hasil dan jasa hutan, pohon dan wanatani;
- Kondisi kesehatan yang lebih baik atau berkurangnya kasus penyakit umum akibat kekurangan gizi di antara kaum perempuan dan keluarganya;

- Lebih banyak perempuan dipilih/ditunjuk sebagai pemimpin dalam komite-komite pengelolaan hutan;

- Lebih banyak kendali (yaitu hak-hak yang lebih kuat) oleh kaum perempuan terhadap sumber daya hutan, pohon dan wanatani pada tingkat rumah tangga dan masyarakat.

- Apakah Anda telah memasukkan pengukuran untuk menilai efektivitas proses pemaduan jender? CIFOR tidak hanya tertarik untuk merekam berbagai keluaran dan hasil yang dibedakan berdasarkan jender, tetapi juga untuk mengetahui sebaik apa jender dipadukan ke dalam proses penelitian. Anda dapat mempertimbangkan untuk memasukkan beberapa indikator untuk mengukur kemajuan untuk meningkatkan kapasitas semisal beberapa pelatihan atau pengembangan pengetahuan mengenai isu-isu jender.

\section{Anggaran}

Dalam penyusunan anggaran Anda, buatlah secara spesifik mengenai sumber daya finansial yang diperlukan untuk berbagai kegiatan terkait jender. Semakin spesifik identifikasi berbagai kegiatan dan keluaran, semakin baik Anda dapat membuat garis besar sumber daya finansial yang diperlukan untuk mendukungnya.

- $\quad$ Apakah Anda sudah menyisihkan tingkat dana yang sesuai untuk melaksanakan berbagai kegiatan terkait jender dari pengumpulan data sampai pembagian dan penyebaran pengetahuan? Anggaran Anda mungkin perlu memasukkan berbagai biaya terkait dengan pelaksanaan survei intra-rumah tangga, kelompokkelompok fokus terpisah untuk kaum laki-laki dan perempuan atau mempekerjakan seorang pakar jender untuktim Anda.

- Apakah Anda telah memasukkan biaya untuk pembangunan kapasitas?

- $\quad$ Anda mungkin perlu menganggarkan pelatihan jender untuk membangun kapasitas di antara tim penelitian, penyensus dan mitra Anda.

- Apakah Anda telah menganggarkan dengan benar untuk memantau dan mengevaluasi berbagai dampak dari penelitian Anda terhadap para penerima manfaat laki-laki dan perempuan?
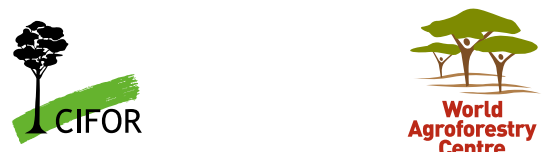